\title{
PHENOMENON OF PSYCHOLOGICAL DEFENSE
}

Elena T. Sokolova

Lomonosov Moscow State University

Moscow

\begin{abstract}
The author discusses the controversial issues of formation and functioning of psychological defense mechanisms in ontogenesis and in personality disorders as they are represented in classical and contemporary psychoanalysis, in cognitivism and communication theory. The paper emphasizes the role of cognitive organization (style), sign-symbolic mediation, representative system of object relations and attachments in individual typological variability of the level organization of defense mechanisms, in efficiency of personal and social adaptation, in maturity and mental health of personality.
\end{abstract}

Keywords: defense mechanisms; psychodynamic, cognitive and communicative theories; ontogenesis and psychopathology, cognitive and symbolic mediation, self-representation, object-representation, personality disorders, behavior deviations.

The study of any psychological phenomenon in the cultural-historical tradition cannot be separated from the scientific reflection on the situation of development of the scientific knowledge about it, i.e., of the conceptual apparatus and the general logic of its development in the context of changing historical conditions. For the mentioned reason, a brief insight into the history of understanding of the phenomenon of psychological defense appears to be necessary.

The notion 'defense mechanisms' emerged in psychoanalysis at the turn of the $20^{\text {th }}$ century and was based on the dominant paradigm of natural scientific thought and positivism; later on it fell outside its limits and acquired polyvalence and blurriness, particularly due to phenomenological, humanistic, and cognitive traditions. Since Freud's first

The work was accomplished with the financial support of the Russian Foundation for Basic Research, grant № 05_06_80240. 
description (1895) of 'defensive actions' of repression in regard to the nature of hysteria and some other neuroses, as well as the analysis of 'the psychopathology of everyday life,' the theory of defense mechanisms (DMs) has been repeatedly revised after the changes in theory of personality, the rethinking of significance of social reality, culture, language and 'semiosphere' as the driving forces and the 'fields' of development of norm and pathology. That is why, when we analyze the phenomenon of DMs, we encounter the variety of frameworks elaborated in every scientific theory, which studies personality problems, and the diversity of views on the genesis, the structure and the functions of DMs. Therefore, here we could hardly offer a complete picture of phenomenology and conceptualization of psychological defenses.

In the contemporary psychoanalytic literature DMs are defined in the most general form as "Group of operations aimed at the reduction and elimination of any change liable to threaten the integrity and stability of the bio-psychological individual... Generally speaking, defense is directed towards internal excitation (instinct); in practice, its action is extended to whatever representations (memories, fantasies) this excitation is bound to; and to any situation that is unpleasurable for the ego as a result of its incompatibility with the individual's equilibrium and, to that extent, liable to spark off the excitation" (Laplanche \& Pontalis, 1996, p. 145). Putting aside the frameworks of specific theories, nowadays we also admit that any psychic phenomena or psychic processes are, in essence, capable of being stimulated by the motive of defense, if they occur in certain conditions (a conflict) and with a specific purpose (to end or alleviate anxiety). It appears reasonable to also speak about DMs as the sui generis 'functional organs' for adaptation to an inexplicit, unforeseen intrapsychic or interpsychic situation that potentially threatens the mind as a whole. They can both facilitate development and personality stability and lead to disorganization and maladjustment, depending on their internal structure, dynamics, level of cultural symbolic and social mediation and, consequently, their maturity.

Despite the long history of research, the problem of psychological defense still remains controversial. Among the most acute issues we would like to emphasize the following: general patterns of formation and reorganization of DMs in ontogenesis; stimulating sources of generation of DMs (intra / interpersonal), functions (defensive / adaptive, destruc- 
tive / constructive); levels of functioning (conscious / unconscious, emotional / cognitive); relation of DMs to other mechanisms of self-regulation; criteria of distinction between archaic (primitive) and relatively late, mature defenses; factors that determine individual typological variability of DMs; pathogenic role of primitive DMs in abnormal development. First of all, let us turn to the analysis of the evolution of ideas on DMs in the psychoanalytic context.

The illustrious 'naturalisticity' of the first Freudian notions about the organismic (almost mechanical) organization of the mental apparatus that follows the biological 'vital rush' and the pleasure principle and is simultaneously forced to obey the reality principle, fully reflected the mentality of Freud as a doctor, a natural scientist and the successor of the Enlightenment. However, he was a broadly educated man of his time, could easily quote classical pieces of world literature and biblical texts, and, especially in his late works, Sigmund Freud started to pay more attention to the problem of cultural and social mediation of impulses, inhibitions, deprivations and regulations, imposed upon unconscious life. According to his speculations, the influence of social institutions, art, science, religion and ethics on a person is far from univocal and grants one an arsenal of various means to subdue the riot of nature outside and inside oneself. Meanwhile, aren't they just more or less sophisticated and attractive illusions (along with manic ideas and neuroses) and, in this sense, the defenses against one's futile efforts to achieve the state of satisfaction (Freud S., 1989)?

Besides, the dualistic conception of motivational sources of defensive actions was formed in the psychoanalytic 'Id psychology': with the help of DMs, the Self as a homeostatic system withstands the excessive intensity of stimulations or incompatibility of instincts and simultaneously seeks to prevent the disintegration of the Self in front of the unbearable demands of reality, represented by cultural restraints and inhibitions. The function of DMs is also dual: DMs are both the obstacles for the direct relief of impulses and the 'cultivated' bypass channels, used for the satisfaction of impulses in a 'masked', surrogate form. Taboos and frustrations (deprivations), which call DMs into being, partly give rise to displeasure and, in this sense, create conditions for a neurotic explosion, but partly they reduce the degree of dissatisfaction to a 'bearable' level. The transformation of the initial impulses up to the 'distortion beyond 
recognition' by means of more complex defense procedures (displacement, symbolization, sublimation, etc.), allows to preserve the relative integrity and the constancy of the Self. Thus, in his early version of the conception of defense S. Freud emphasized the threat to the integrity of the Ego from the instinctive impulses of the Id, which are corporal in nature. The secondary processes (the Ego and its functions: defenses, cognitive processes), which conform to the reality principle, were regarded - along with the primary processes, such as dreams, fantasies, free associations - simply as a source of additional means for the realization of impulses. Therefore, DMs were defined as the unconscious, automatically launching means of regulation of the Id-Ego conflict and its generated anxiety, which attend to the 'primary', instinctive, affective and, in whole, irrational processes. Besides DMs, which transform impulses and their derivatives, such forms of illusory change of reality that serve the acquisition of pleasure, i.e., hallucinations, fantasies, daydreams, child's symbolic play, art, etc. were distinguished.

In his later works dedicated to narcissism and paranoia, Freud's scientific interest was focused on the study of the destructive and pathogenic role of the death instinct, the moral masochism and the instincts of self-preservation, which oppose them. From that moment, along with the necessity to defend the Ego against the immoderate demands of the Id, S. Freud also postulated the necessity of self-protection against the stern, punishing, aggressively 'charged' Super Ego, represented by the internalized, excessively harsh moral demands of parental figures and the threat of castration due to the lack of idealized and supportive representations of parental Objects. Here the jeopardized psychic space is integrity and unity of the Self, constancy of self-respect. Anxiety is awakened by the fear of losing a libidinal (loving) Object and, along with it, the Self (as in melancholia), or by the fear of any other 'narcissistic wound' from a frustrating parental figure; primitive magical ideas of personal grandeur, omnipotence of feelings, thoughts and actions are reactivated in order to protect the Self (Freud S., 1991).

A considerable contribution to the development of the psychoanalytic theory of DMs was made by the representatives of ego psychology, who directly concentrated on the study of structural organization of the Self, which, according to H. Hartmann, possesses the functions not only subservient to Id, but also independent of it, and the most sig- 
nificant function is the acquisition of individual and effective means of adaptation to the complex social reality (Hartmann, 2002). The shift in emphasis towards the social conditions of development, which compel children to overcome normal socialization crises, called for the revision of the notion of DMs from the perspective of their contribution to constructive interaction with interpersonal environment, devoid of irrational conflict of primary impulses. New concepts were formed, such as: control and coping mechanisms, force of the Ego, pattern of DMs and individual style of adaptation, which indicated that the role of social education in amplification and reorganization of systems of self-control was acknowledged (Sokolova, 2002). A. Freud significantly enriched the conception of sources of anxiety, as she was the first to point out the role of DMs in alleviation and transformation of anxiety, associated with interpersonal relations. Thereby, along with protective distortion, she emphasized the function of DMs in securing adaptation and supporting structural integrity of the Self in interaction with the closest social environment during certain ontogenetic stages (Freud A., 1993). She created a new model of relation between the Id and the Ego, which made it possible to outline the vectors of development of the progressive structuring of the child's inner world with regard to the world of reality. In the process of this reorganization, "the inner world is taken under control and the freedom of impulses and fantasies is gradually limited in order to give place to rationality and sufficient ego-control" (Burlakova \& Oleshkevich, 2005, p. 94).

The conception of systemic organization of 'secondary processes' (memory, perception, cognition) and structural instruments of control (known to be independent of the instinctive conflicts of ego-functions) was firmly established in the ego psychology and proved to be important for the development of perspectives on DMs. Though innate, these processes become more complex and hierarchical in the course of development, they acquire the ever-increasing autonomy from the primary instinctive impulses, which leads them to a more accurate, effective and accessible to consciousness 'adjustment.' It appears to us that the premises for the development of the systemic and integrative model of self-regulation were created within the ego psychology due to the distinction between primary unconscious DMs, directly dependent on impulse conflict, and secondary 'control mechanisms', based 
on cognitive dissonance and relatively independent of influence from impulses, more flexible, individualized, within the reach of awareness (Sokolova, 2002; Sokolova, Burlakova, \& Leontiu, 2001; Sokolova \& Sotnikova, $2006 \mathrm{a}, \mathrm{b})$. We should also note that further integration of psychoanalysis, cognitive and evolutionary psychology considerably promoted the creation of experimental models and the modification of quasi-experimental methods of research (in particular, the projective ones) on 'cognitive control', coping mechanisms and their consistent patterns, which constitute the individual affective cognitive style that influences the nature of mental (perceptive, mnestic, cognitive) representations of the Self and others, the strategies and the emotional tone of relationships established with parental figures (so-called Objects) (Sokolova, 1989, 1995).

The area of the psychoanalytic research was significantly expanded with the introduction of the new conceptual apparatus into common scientific use: studies entered the interdisciplinary context, joined the problematics of cognitive psychology, traditionally 'usurped' by academic psychology, and aroused an unprecedented interest in the socio-psychological, communicative and individual- subjective aspects of human cognition. In its turn, the alliance between cognitivism and psychoanalysis produced new perspectives in cognitive psychology itself, which for a long period of time had remained 'sterile,' artificially isolated from subjective mediation of human cognition. It affected issues of the development of cognitive processes, the formation of their structural organization in childhood (including organization of the respective brain structures), the cross-cultural and individual typological cognitive differences, the importance of communicative context and the intentional determination of cognitive activity, where a subject builds some intrapsychic representative systems. It is no mere chance that in 1950-1960's the New Look at the projective methods became exceptionally popular: it viewed them as the instruments of indirect and guided 'experimental' personality research through the study of perceptive and, even broader, cognitive individual organization of consciousness (personality style), of configurations of unconscious DMs and connected with rational processes coping strategies of solving any problems or complicated life situations (in 1954, a book by $\mathrm{H}$. Witkin with a notable title Personality through Perception was published in the USA). 
When analyzing the altered scientific context, we observe the gradual transformation of views on the nature of DMs. It becomes more and more obvious that those mechanisms, which were historically accepted to be called DMs, are a part of the wide range of one's adaptive functions, executed by the hierarchically organized constellation of all psychic processes as some sort of a 'functional organ,' when occurs an uncertain, unforeseen situation, threatening to the mind as a whole. There appear new perspectives of understanding of structural heterogeneity and heterochrony of DMs; one starts to associate their dynamics with the conditions of passing through ontogenetic phases, with individual personal features, character accentuations and type of psychic pathology. Being regarded as Ego and Super Ego structures, DMs are characterized by relative consistency and hence may coalesce with the Self so tightly that are subjectively perceived as 'natural' inseparable character traits, become Ego-syntonic, automatically reproducible and hard to transform under the influence of life events or psychotherapy. The mature defenses (suppression, isolation, rationalization, reflection, identification, altruism, sublimation) imply cognitive elaboration and symbolization, which facilitate improvement of the functions of regulation and adaptation, resolution of the Oedipal conflict, internalization of the relatively consistent patterns (affective and cognitive schemes) of social relations. The emergence of the primitive DMs (splitting, projective identification, idealization / devaluation, grandiosity) is attributed to the pre-Oedipal period of child's personality formation; in their structure they still remain 'tied' to the sensually physical and affective sphere of mental life and, if they continue to dominate in adulthood, they do not cope with the tasks of harmonization and stabilization of the Self and object relations (Kernberg, 2001 a, b; Klein, 1998; MacDougall, 2007).

Thus, new prospects for studying DMs begin to show within the psychoanalysis, and namely in the theory of object relations; they are aligned with the appearance of a specific interest in the pre-Oedipal stages of formation of the Self and in the clinical picture of the borderline and narcissistic disorders (M. Klein, M. Mahler, O. Kernberg, etc.). In this theory, the relations between the Self and subjects of primary attachment (Objects, in the specific psychoanalytical terminology) are considered as the sources and the driving forces of development; when internalized, these relations are transformed into the mental Self and Object represen- 
tations. It is thought that the representations of the object relations differ in the degree of affective and cognitive fragmentation (differentiation), internal connectedness (articulation), mutual consistency (coherence), clarity of boundaries (Kernberg, 2001 a, b; Klein, 1998). DMs are involved in the primary, affectively charged relations with the Object and serve their regulation (Kernberg, 2001 a, b; Gunderson, 2001; Kernberg, 1993; Leichsenring, 1999; Lerner, 1996).

The sphere of functioning of the primitive (pre-Oedipal) DMs is the interpersonal space between the Self and Object; they participate in the dynamic intrapsychic processes of merging / differentiation of the Self and Object representations and also contribute to the setting of boundaries between the Self and the Other, to the regulation of trust / hostility, autonomy / symbiosis, separation and cooperation, and in this sense DMs facilitate or block the formation of the sense of autonomous identity. The primitive DMs are oriented towards overcoming the unbearable horror, derived from the perception of the Object as both satisfying and frustrating, absolutely and forever merged with the Self or forever separated and lost. Based on the rough splitting of integral representations of the Self and Object, on their relations, DMs generate a distortion in the representation of reality, they prevent the realization of integrity, autonomy and consistency of Objects, which exist outside and independently of satisfactions or frustrations of the Self.

The mature DMs function differently: they operate in the intrapersonal space and contribute to the formation of boundaries between the Id, the Ego and the Super Ego, as well as to the subtle structural differentiation and integration of these personality constituents. The mature defenses also serve the purpose of the distinction between observing, reflecting and sensing Ego aspects; they help to achieve Self integrity and Object constancy; due to them there appears a possibility of a less painful resolution of the Oedipal conflict and a chance for a child to enter a social community that is wider than a family. Qualified to preserve and protect the 'assembled' Self-Other relations, the mature DMs repress, revise or contain by other rational means one or another part of representation of the threatening object relations or bodily-sensual experience.

Modern psychoanalytic theories postulate that the development of cognitive processes and relationships with Objects is carried out due to 
the two-way connections between them: a secure attachment relationship sustains the formation of cognitive processes and actions of defense; the latter, in turn, promote greater feasibility of object representations, their greater 'reasonableness', due to the expanding and complicating repertoire of cognitive tools (Fonagy, 2002; Fonagy, Target, \& Gergely, 2000). On the contrary, the mental Self and Object representations are susceptible to distortions caused by unconscious fantasies, while individual cognitive organization is specifically vulnerable to certain stressful life events, when object relations are destructive and harmful, generate the so-called disabling environment. For example, the famous British psychoanalyst W. Bion believed that infant introjects the maternal function of transformation of the over-stimulating and painful affects and thus gains the ability to protect himself on his own, to resist and to regulate (to contain) his own distressing mental and painful somatic states (MacDougall, 2007; Bion, 1967). Similar idea can be found in D.W. Winnicott's discussion of intermediate (symbolic) space between infant and mother, 'transitional objects' (cuddly toys, corner of a blanket) and more primitive, still devoid of integrity, fragmentary precursors of the Object: noises, smells, touches, which remind of the permanently available satisfying mother and act as a substitute for the mother's supportive attitude, 'holding' (Winnicott, 2000).

In our opinion, a considerable (and not fully valued) contribution to the understanding of the intersubjective purpose and the intentional determination of DMs was made in Watzlawick-Gregory-Bateson interpersonal communication theory; in particular, we refer to the proposition about the pathogenic role of the paradoxically absurd communicative patterns as triggers of personality psychopathology. Studied by Palo Alto researches, the phenomenon of the double bind generates the states of schism, absurdity and hopelessness in participants of communicative situation, as well as affective disorganization, intellectual stupor and state of the schizophrenic madness (Watzlawick, Beavin, \& Jackson, 2000; Singer, Wynn, \& Toohey, 1978). We have assumed that the ambiguously paradoxical communication tactics (or transactions, tricks and traps) serve an important function: with their help, the unconscious tries to conceal its true motives and simultaneously make them 'palpable' for the partner, 'reach' him directly by means of 'merging' with him in affective contamination, seduction, bribery, pressure 
or control (Sokolova, 1989, 1995, 2003). In psychotherapy of borderline patients these tactics are reproduced in the relationship of paradoxical and unsolvable transference / counter-transference, when therapist and patient are pulled into the vicious circle of tangled and unsolved infantile conflicts of separation / individuation, and when their mutual interactions are induced by the opposing desires for merging / autonomy. In D. Anzieu's opinion, such communicative patterns are the reason of the so-called negative therapeutic reaction: "My behavior is hampered in the course of this therapy: if I stay neutral and discreet, I am perceived as rejecting and her depression grows; if I interpret, then the minimal awkwardness of tone, style or meaning on my part is perceived by her as a disapproval, and nothing remains for her but to plunge into depression. Thus, whatever I do and don't do, she experiences a failure and so do I" (Anzieu, 2005, p. 218). For the participants of this interaction the solution of this logical paradox can be found in the establishment of a meta-communicative situation with the possibility of both reflective understanding and working-off and empathic insightful grasp of meaning of a masked meta-communicative message directed to the therapist, the same that was directed to parental figures, but was not 'read' by them and did not get a reciprocal empathic response (Sokolova, 1995, 2002).

These observations tell us a great deal about the communicative genesis of DMs, about the factors of their reactivation in psychotherapeutic situation, which are related to both patient's and therapist's representative schemes. The possibility of therapeutic changes and patient's stay in therapy considerably depends on therapist's ability to flexibly change the therapeutic strategy: to accept patient's projective identifications and related transactions in order to 'get a gut feeling' of the message on the first stages of the process, and, on the advanced stages of the therapy, to gently repudiate their forced nature.

Let us draw some conclusions. The development of the theory of DMs has had several trends: from the narrow intrapsychic concept of the genesis and the functions of DMs to the acknowledgment that DMs are intrinsically embedded in interpersonal relationships. They structurally organize these relationships in accordance with the vital needs of the Self to maintain a secure emotional bond with the Other without losing individual integrity. The notion of the development of DMs has 
undergone significant changes: there emerged an idea of the structural and hierarchical organization of DMs, which considers their connection with other mechanisms of personality regulation. Nevertheless, there still exists an ambiguity in the criteria of differentiation between them and the mechanisms of coping behavior - a strategic repertoire of active and constructive interaction with problems, critical or stressful situations. On the one hand, it is claimed that DMs are the low-efficient and primitive mechanisms of coping; on the other hand, it is assumed that there is a gradation of DMs on the degree of agency and stress resistance. At the same time, some of DMs may approximate to coping mechanisms. As opposed to unconscious DMs and, in a certain sense, to their innate reflex means of regulation of affective conflict, copings are considered as conscious strategies of interaction with reality, acquired through active learning. Thus, the difference between defense mechanisms and coping is presented by the differing degree of awareness, reflectivity, intentionality, control, agency in the interaction with reality (Konopkin, 1995; Nartova-Bochaver, 1997). We also assume the possibility of transformation of DMs into copings; particularly, in psychotherapy, when the patient acquires the ability of verbalization, reflection and awareness of the conflict as the implicit source of DMs, he can also choose and intentionally exploit various defenses, which used to be necessary for survival in the past, but have become pointless or harmful at present. In that case, DMs are able to transform into rational, constructive, essentially new strategies of solution and revision of subjectively difficult situations. Defenses lose their obsessively recurring dynamics and chronic ability to distort inner and outer reality; they are 'neutralized' and lifted to a more mature level of functioning.

The functional effect of mature DMs can be compared to conscious, conceptual, systemically organized and intentional, culturally mediated regulation of behavior. According to the propositions of the cultural-historical approach, the function of self-regulation emerges through sign mediation; the function itself is a new formation, which appears in ontogenesis due to interiorization of means and methods of mutual influence of mother and infant. The ability of social and cultural mediation with the help of cognition and speech is recognized as the most significant quality of human development in norm and pathology, since it is the necessary condition of the autonomous regulation of one's behavior 
and one's own life in whole (Vygotsky, 1983; Zeigarnik, Holmogorova, \& Mazur, 1989; Leontiev, 1995; Sokolova \& Nikolaeva, 1995). However, thus far, only negative function of DMs is emphasized: DMs hinder the process of reflection, distort the realization of virtually active motives and meanings. The adaptive function of DMs is excluded on the basis that DMs represent "the refusal of meaning-building, which is necessary in the given life situation, the transferal of the conflict solution from the dimension of subject's real life to the dimension of mind" (Leontiev, 1995, p. 264).

Meanwhile, it appears to us that this statement is justified only for the primitive DMs. The mature DMs are the product of transformation of primarily natural (in Vygotsky's terms), organismic and psychic adaptive processes in the 'mother-child' relationship. Responding to the requirements of development, DMs participate in the dynamic processes of differentiation and integration of boundaries between the Self and the Other, as well as in the regulation of trust / hostility and autonomy / cooperation relationship. As they develop, DMs, as the compromise formations (a kind of mediators) between impulses, motives, affects on the one hand, and the processes of acquisition of reality on the other hand, participate in more and more accurate adaptation to social environment, simultaneously contributing to (or interfering with) the construction of the stable mental (cognitive affective) Self and Other representations. DMs are heterochronic and heterogenic in their structure. Their maturity and efficiency are determined by the balance of interaction between components, differing in their nature: from automatic and unconscious to reflective, conscious and controllable; from direct perceptional, motor and affective to rational and creatively intuitional (fantasies), mediated both by cultural contents, standards of social consciousness and by individual symbolism. In ontogenesis, they rise from natural and primitive to mature, mediated by signs and symbols, 'tuned' to the solution of more and more complex tasks of organization of self-identity in its relations with social environment. Among these tasks, special demands are placed on efficiency of DMs in the regulation of cooperation / autonomy relationship with significant Others, on competence in social perception and communication in the conditions of experiencing personal crisis that threatens with a brutal destruction of the established attitudes toward the Self and significant Others. So it is no mere chance that, for 
example, contemporary clinical psychology discusses the role of the deficiency of mature, cognitively mediated DMs and effective coping strategies as the triggers of personality disorders and autodestructive behavior (Kernberg, 2001 a, b; Sokolova \& Sotnikova, 2006 a,b; Gunderson, 2001; Kernberg, 1993; Leichsenring, 1999).

In turn, our empirical studies point at the connection between the strategies of intrapsychic and interpersonal protective self-regulation and the affective cognitive style, the nature of personality pathology and the broad spectrum of autodestructive self-regard: suicide, addictions, promiscuity, hostility toward self and others (Sokolova \& Nikolaeva, 1995; Sokolova, 1989, 2002, 2003; Sokolova, Burlakova, \& Leontiu, 2001; Sokolova \& Sotnikova, $2006 \mathrm{a}, \mathrm{b}$ ). The marked field dependence and the low level of cognitive differentiation correlate with one of the syndromes of borderline personality organization that includes (1) instability and fragmentariness of the structural and functional organization of selfidentity, tendency to inverted gender self-awareness, (2) low tolerance for ambiguity and frustration from significant Others, hyper-compensated by the intrapsychic and interpersonal manipulative defensive strategies, (3) domination of the primitive, natural DMs along with the lack of cognitive mediation and symbolization, highly biased Self and Object representations, their negative affective charge. Besides everything else, high field dependence implies excessive concreteness, narrowing of possibilities to transcend the present, the directly given, including by means of imagination and dream; it inhibits the anticipation of the future, the metaphorical reconstruction of the missing and the lost, and thus it significantly lowers the regenerative resources of personality, maintaining the state of chronic 'emotional hunger,' of constant dissatisfaction. Low differentiation ('cognitive simplicity' and lack of instruments of analysis) manifests itself as incapability to notice subtle differences and changes (especially in the sphere of social relations and self-perception), as generally 'dichotomical', non-dialectical cognition.

In psychotherapy of 'difficult' borderline and psychosomatic patients, the listed features are one of the psychological mechanisms of general resistance to therapy, of sabotage of cooperative relationships; they restrict patents' ability to experience relief and at least partial satisfaction from therapeutic analysis and support (as a verbal analogy of Winnicott's 'holding') with the help of words, and not actions or 'things.' This forms a 
vicious circle of interrelated and mutually sustaining affective, cognitive and communicative disorders.

Many authors within the framework of object relations theory pay attention to the specific cognitive deficiency of the borderline patients. Thus, according to some experts, scarce availability of the processes of symbolization may be considered as the main cognitive damage in borderline personality disturbances. The consequence of this defect is a peculiar structure of the inner world, filled with specific events or abstract ideas, but lacking 'mentality': reflections, ideas, fantasies, associations, as well as metaphors, meanings and emotional fullness (Marty \& M'Uzan, 2000; Sokolova, 2003). Operational thinking, as it is called in the French school of psychoanalysis, is bare and lifeless, 'devitalized' and static. Therefore, the degree of cognitive and symbolic mediation can serve as the criterion of complexity, versatility, inner coherence and integrity of the Self and Object representations, understood as symbolic forms of relations and defenses.

Certain authors suppose that the structure of DMs includes affective and cognitive processes, which influence the degree of differentiation and integrity, as well as emotional tonality of the Self and Object representations (Blatt \& Lerner, 1983; Lerner, 1996). Other authors emphasize the secondary nature of this cognitive impairment and link its genesis with the absence of interiorized and constant Object (Lerner, 1996; Muller, 1996) that blocks the formation of mental relations.

The French school of psychoanalysis distinguishes several levels of mentalization, depending on the development of cognition and the degree of separateness from corporal processes: 1) primary mentalization virtually shows the absence of reflection due to the merge of the mind with motor activity and corporal processes, 2) secondary (symbolic) mentalization occupies the intermediate position between sensory activity and imagery, 3 ) verbal cognition provides both mobility and constancy of the inner experience (Fonagy, 2002). The authors acknowledge the intermediate position of the symbol, between the 'pure absence of imagery, experience, sensori-motor intelligence (Orban, 1998; Piaget, 1983) and somatization (Marty, 2005) on the one hand, and the objectness of perception, reflection on the objective reality with the help of logical cognition that operates with rules and signs, on the other hand. 
The necessity for symbol originates from the intersubjective nature of the mind, the initially undifferentiated unity of mother and infant; and one of the first functions of symbol consists in substitution of the real Object, in creating its simplest image as a protective buffer between the Self and the experienced loss of its former merge with the Object. Due to formation of symbolic representation of the maternal object, the psychological separation becomes possible; there occurs a birth of individuality (autonomous identity), along with personal space, privacy and intimacy. A new communicative situation emerges, in which, in order to reunite with the Other, the subject has to overcome loneliness that follows the birth of the Self and to recreate 'in mind,' on the symbolic level, the missing communicative and emotional bonds with this Other, and this time to merge with the Object in a single whole not in reality but 'visionary.' Apparently, interaction, enriched with symbolic mediations, acquires in its turn completely new qualities; it leads to communication proper between the Self and the Other, between the two autonomous and individual Selves. Moreover, as the more mature means and methods of symbolic and semantic reorganization of the intrapsychic world join in, there appear new degrees of freedom of its transformation. Thus, the development and the complexity of DMs are realized by cognitive processes through acquisition of means and methods of symbolic mediation. Meaning-making qualitatively changes the system of cognitive processes: it becomes possible for the subject to understand conditionality, figurative sense, imagery, humor. By creating the imaginary reality, one acquires deeper empathic understanding of self and others, one is able to cherish comforting dreams and illusions, which replace losses and disappointments.

The acquisition of symbol allows overcoming both the chaotic state of horror of vagueness and ambiguity of the introceptive world and the rigid univocacy of the object reality; it presents itself as the creative act of uniting word as an external, not yet acquired sign, and 'overflowing' affects. The combination of 'alien,' unacquired reality and vivid direct experience is the symbolization per se. Within the cultural-historical approach, the given levels of mentalization can be understood as the levels of mediation; while symbol, in its turn, can be seen as an intermediate link, a peculiar 'syncretism' (according to L. Vygotsky), which is no longer 'concrete,' but still is not 'abstract.' Originally, primary impulses, 
affects and defenses are directly included in symbiosis with the object of attachment and are regulated by the predominantly natural, organismic, instinctive DMs. However, though they are initially embedded into the developing 'mother-child' relationship, they are mediated by symbols and transform into more mature mechanisms with a more efficient compensatory function due to interiorization of the increasingly complex 'intermediate' symbolic space, play, fantasy and imagination.

D.W. Winnicott (Winnicott, 2000) attributes to symbolization the function of the mediator (transitional third link) between the primary bodily-affective experience and reality. It appears on the Oedipal stage of development, when the subject enters into triadic relations, and serves the purpose of achieving and maintaining 'coherence' of the Self, containment of affect and development of concepts, relatively independent of concrete situations and evoked feelings. The formation of symbolic representations results in the renunciation of 'acting out' of desires and in the availability of satisfaction via 'trial action of thought' and imaginative play, which postpones the impulsive resolution of drives and affects and broadens the range of substituting objects of satisfaction.

The problem of symbolization of the inner world is discussed in a number of the studies on personality disorders. For example, the insufficient acquisition of means of symbolization is considered to be the main cognitive impairment in borderline personality disorders, which, in turn, is generated by the instability of the Self and the inner Object (Sokolova \& Nikolaeva, 1995; Sokolova, 1989, 2002, 2003; Sokolova, Burlakova, \& Leontiu, 2001; Sokolova \& Sotnikova, 2006 a, b), by the absence of representative experience of secure attachment (Fonagy, 2002; Fonagy, Target, \& Gergely, 2000). In some studies, the degree of symbolic mediation of the inner world is regarded as a connecting link between the Self and Object representations on the one hand, and DMs on the other hand; and, which is equally important, is considered as a basic criterion for the severity of personality disorders. It is claimed that the secure attachment, the stable presence of a 'good' Object releases the resources, needed for the full development of symbolic function, cognitions and mature DMs; thereafter, when the attachment is disrupted, the significant damage of the symbolic function should be anticipated (Fonagy, 2002). In this way, for example, the temporal blocking of symbolic function and, accordingly, of DMs of a higher degree and logical thinking in whole may be- 
come the survival condition in incestuous relationship, in psychological and physical violence. Even longer delays in development are possible, accompanied by a sort of mental and spiritual death. The British psychoanalytic P. Fonagy deduces the genesis of DMs from the specific patterns of attachment and the repertory of caregiver's defenses, which are mobilized in response to infant's distress: thus, a rejecting mother may fail in empathic mirroring of child's distress, while a worried mother may interpret child's state in an exaggeratedly anxious way. In either case, a child is practically robbed of the opportunity to internalize an accurate and undistorted mental representation of his psychic state, but for the sake of intimacy with the caregiver his reflective and empathetic functions will be sacrificed (Fonagy, 2002; Fonagy, Target, \& Gergely, 2000). In whole, secure attachment relationships or stable representations of object relations are acknowledged to play the most significant role in the development of processes of symbolization, complex cognitive functions, styles of affective regulation, and repertory of DMs.

Clinical observations and experimental research indicate that there exist several versions of damages of the symbolic function of cognition. The first one is based on the disjunction of sensual-affective experience and meaning-making, whereupon the cognition uses an array of highly differentiated, over-abstract, but lifeless, emotionally emasculated, 'devitalized' associations and symbols with a streak of grandiosity, perfectionism and magical power. It is precisely what we find in pathological narcissism and schizoaffective psychoses. On the contrary, in certain borderline, psychosomatic personality disorders and somatic depression, cognition is characterized by excessive concreteness, situational 'lock-up' in time and space, overdependence and insufficient offset from the influence of 'immediate' present field and the intensity of actual motivation, of dominating and 'flooding' affect, which erases the coordinates of reality. Upon that, secondary rational DMs are blocked due to the inaccessibility of the function of symbolization; cognition falls in service of intensive affect, starts to work in the energy-saving mode and, for the purpose of protection, simplifies the worldview to primitiveness and splits it into the absolutes of unrealizable, unobtainable and omnipotent 'goodness' and eternal, totally worthless and threateningly haunting 'badness.'

To the defenses, which are appropriate in early infancy and transient in normal development, but remain dominating in borderline personal- 
ity disorders (splitting / projective identity, globalization, omnipotence / devaluation), the specific alexithymic phenomena are added. In behavior, psychosomatization and motor abreaction of affects and emotional experience are accompanied with evident difficulties of verbalization of psychic states and with tendencies to direct destructive impulses at one's own corporal Self. The analogical function is also realized through various sorts of 'perversions' of instinctive organismic life: from sleep disturbance, dysorexia, libido disorder to 'self-mutilation', which is relatively acceptable in culture (burning, scarification, piercing, tattooing, impetuous immersion into fitness, narcissistic perfection of appearance by means of aesthetic surgery). The traces of primitive motor abreaction are also found in self-injuries, chronic suicidal attempts, as well as in other obsessive addictive actions (binge-eating, drug use and sticking to another person in search of momentary ersatz- soothing) (Sokolova, 2003, Sokolova \& Sotnikova, 2006 a, b). Culturally normative and value-semantic regulators of life activity, such as conscience, guilt and shame, - the means of moral and ethical self-regulation for a human with a mature personality, in people with narcissistic vulnerability of self-respect and difficulties of symbolization are either completely inefficient or somatized for the purpose of defense, transformed into body torment. In such a state, one looses not only the ability to experience gladness and enjoy life, but also to play, invent, and insightfully see ordinary and usual things in a new light. Here the analogy with infantile apathy and delay in cognitive development in response to prolonged deprivation of mother's love and attention is quite pertinent. The absence of the Object in reality, uncompensated by its symbolic supportive representation in the inner world, leads to the irretrievable loss of bonds of various nature, such as confidentiality and intimacy in communication, to cognitive deficit, to the loss of consistency and coherence of mental representations. The world inside and outside of the Self appears in the primordial chaos and total ambiguity, out of the spatial and temporal coordinates, without the possibility to be expressed in words, to acquire structure and order, and that cannot but fill a person with confusion and global helplessness. The systemic organization of DMs is forced to function in a simplified mode, returning to an earlier ontogenetic level of cognitive mediation (cognitive simplicity), or completely looses the ability of rationality and verbalization. 
The case is somewhat different, when the experience of 'loss' is accessible to sharing with the Other, to symbolization, imagination and verbalization; due to this it goes through culturally developed rituals of 'mourning' and becomes contained by them. "Words," notes J. MacDougall, "are invaluable containers" (MacDougall, 2007). Containment, as a mature defense, serves the purpose of integration and achievement of non-contradictory unity of emotional attitude and mental representation, of 'gathering oneself' in sensible and holistic self-identity, maintained despite the vicissitudes of life experience. As a product of interiorization of communication patterns from early family environment, which are the vitally important means of consolation, support, maintenance of self-respect, control for satisfying communicative needs, higher DMs become the 'style' 'functional organs' of personality, which characterize its individual system of establishing emotional and meaningful bonds with oneself, other people and the outside world.

\section{References}

Anzieu, D. (2005). Paradoksalnyj Transfer. Ot Paradoksalnoj Kommunikacii k Negativnoj Terapevticheskoj Reakcii [Paradoxical Transference: From Paradoxical Communication to Negative Therapeutic Reaction]. In A. Jibo \& A. Rossohin (Eds.), Frantsuzskaya Psikhoanaliticheskaya Shkola [French Psychoanalytic School] (pp. 206226). St.-Petersburg: Piter.

Bion, W. (1967). Attacks on Linking. In Second Thoughts. New York: Jason Aronson.

Blatt, S., \& Lerner, D.H. (1983). The Psychological Assessment of Object Representation. In Journal of. Personality Assessment, 47, 7-28.

Burlakova, N., \& Oleshkevich, V. (2005). Detskij Psikhoanaliz. Shkola A. Frejd [Child Psychoanalysis: School of A. Freud]. Moscow: Akademia.

Fonagy, P. (2002). Tochki Soprikosnoveniyua i Rashozhdeniya Mezhdu Psikhoanalizom i Teoriej Privyazannosti [Points of Contact and Divergence between Psychoanalytic and Attachment Theories]. Zhurnal Prakticheskoj Psikhologii i Psikhoanaliza, 1, March. E-print: http://psyjournal.ru/j3p/pap.php?id=20020105.

Fonagy, P., Target, M., \& Gergely, G. (2000). Attachment and Borderline Personality Disorder: A Theory and Some Evidence. Psychiatric Clinics of North America, 23 (1), 103-122.

Freud, A. (1993). Psikhologiya Ya i Zaschitnye Mehanizmy [Ego and the Mechanisms of Defense]. Moscow: Pedagogika Press. 
Freud, S. (1989). Buduschee Odnoj Illyuzii [The Future of an Illusion]. In A. Yakovlev (Ed.), Sumerki Bogov [The Twilight of the Gods] (pp. 94-142). Moscow: Politizdat.

Freud, S. (1991). O Narcizme [On Narcissism]. In S. Freud, Ja i Ono [The Ego and the Id] (vol. 2, pp. 107-133). Tbilisi: Merani.

Gunderson, J. (2001). Borderline Personality Disorder: A Clinical Guide. Washington, DC: American Psychiatric Association.

Hartmann, H. (2002). Ego Psikhologiya i Problema adaptacii [Ego Psychology and the Problem of Adaptation]. Moscow: Institut Obschegumanitarnyh Issledovanij.

Kernberg, O. (1993). The Suicidal Behavior in Borderline Patients: Diagnosis and Psychotherapeutic Considerations. American Journal of Psychotherapy, 47(2). 245-254.

Kernberg, O. (2001a). Suicidal Risk in Severe Personality Disorders: Differential Diagnosis and Treatment. Personality Disorders, 15(3), 195-208.

Kernberg, O. (2001b). Tyazhelye Lichnostnye Rasstrojstva. Strategii Psikhoterapii [Severe Personality Disorders: Psychotherapeutic Strategies]. Moscow: Klass.

Klein, M. (1998). Emocionalnaya Zhizn Rebenka [Some Theoretical Conclusions Regarding the Emotional Life of the Infant]. In A. Porschenko, \& I. Romanow (Eds.), Psikhoanaliz v Razvitii: Sbornik Perevodov [Psychoanalysis in Development: Collection of Translations] (pp. 59-108). Ekaterinburg: Delovaya Kniga.

Konopkin, O. (1995). Psikhicheskaya Samoregilyaciya Proizvolnoj Aktivnosti Cheloveka: Strukturno-Funktsionalnij Aspekt [Mental Self-Regulation in Voluntary Activity: Structural-Functional Aspect]. Voprosy Psikhologii, 1, 5-12.

Laplanche, J., \& Pontalis, J. (1996). Zaschita, Mehanizmy Zaschity, Mehanizmy Otrabotki [Defense, Defense Mechanisms, Working-off Mechanisms]. In Slovar po Psikhoanalizu [The Language of Psychoanalysis] (pp. 145-149, 227-231). Moscow: Vysshaya shkola.

Leichsenring, F. (1999). Splitting: An empirical study. Bulletin of the Menninger Clinic, 63(4).

Leontiev, D. (1995). Psikhologiya Smysla [The Psychology of Meaning]. Moscow: Smysl.

Lerner, P.M. (1996). Rorschach Assessment of Cognitive Impairment from an Object Relations Perspective. Bulletin of the Menninger Clinic, 60(3), 351-366.

MacDougall, J. (2007). Teatry Tela [Theatres of the Body]. Moscow: Cogito-Centre.

Marty, P. (2005). Psikhosomatika i Psikhoanaliz [Psychosomatics and Psychoanalysis]. In A. Jibo, \& A. Rossohin (Eds.), Frantsuzskaya Psikhoanaliticheskaya Shkola [French Psychoanalytic School] (pp. 514-525). St.-Petersburg: Piter.

Marty, P., \& M'Uzan, M. (2000). Operativnoe Myshlenie [Operational Thinking]. In A. Rossohin (Ed.) Antologiya Sovremennogo Psikhoanaliza [Anthology of Modern Psychoanalysis] (pp. 327-336). Moscow: Institut Psikhologii RAN. 
Muller, J.P. (1996). Beyond the Psychoanalytic Dyad: Developmental Semiotics in Freud, Peirce and Lacan. New York: Routledge.

Nartova-Bochaver, S. (1997). "Coping Behavior” v Sisteme Ponyatij Psikhologii Lichnosti ["Coping Behavior" in the Framework of Personality Psychology]. In Psikhologicheskij Zhurnal, 18(5).

Orban, P. (1998). O Processe Smysloobrazovaniya [About the Meaning-making Process]. In A. Bokovikov (Ed.), Enciklopedia Glubinnoj Psikhologii [Encyclopedia of Depth Psychology] (vol. 1, pp. 532-569). Moscow: MGM Interna.

Piaget, J. (1983). Schemy Dejstviya i Usvoeniye Yazyka [Schemes of Action and Language Learning]. In Ju.S. Stepanov (Ed.), Semiotika [Semiotics] (pp. 133-136). Moscow: Raduga.

Singer, M., Wynne, L., \& Toohey M. (1978). Communication Disorders and the Families of Schizophrenics. In L. Winne, R. Cromwell, \& S. Matthysse (Eds.), The Nature of Schizophrenia: New Approaches to Research and Treatment. New York: Wiley Medical.

Sokolova, E. (1989). Samosoznanie i Samoocenka pri Anomaliyah Lichnosti [SelfConsciousness and Self-Esteem in Abnormalities of Personality]. Moscow: Izd-vo Mosk. un-ta.

Sokolova, E. (1995). Izuchenie Lichnostnyh Osobennostej i Samosoznaniya pri Pogranichnyh Lichnostnyh Rasstrojstvah [The Research on Personality Traits and SelfConsciousness in Borderline Personality Disorders]. In E.T. Sokolova, \& V.V. Nikolaeva, Osobennosti Lichnosti pri Pogranichnyh Rasstrojstvah Lichnosti i Somaticheskih Zabolevaniyah [Personality Traits in Borderline Personality Disorders and Somatic Illnesses] (pp. 27-206). Moscow: Argus.

Sokolova, E. (2002). Psikhoterapiya: Teoriya i Praktika [Psychotherapy: Theory and Practice]. Moscow: Academia.

Sokolova, E. (2003). Chelovek-Narciss: Portret v Sovremennom Sociokulturnom Kontekste [Human-Narcissist: Portrait in Modern Socio-cultural Context]. In A. Zhuravlev, \& N. Tarabrina (Eds.), Psikhologiya: Sovremennye Napravlenyya Mezhdicsiplinarnyh Issledovanij: Sbornik Statej (Materialy nauchnoj konferencii, posvjaschennoj pamjati chlena-korrespondenta RAN A.V. Brushlinskogo, 8.10.2002) [Psychology: Modern Tendencies of Interdisciplinary Research: Collected Papers (Materials from the scientific conference in the memory of the corresponding member of the Russian Academy of Sciences A. Brushlinskij, 8 oct., 2002)] (pp. 126-138). Moscow: Institut Psikhologii RAN.

Sokolova, E., Burlakova, N.S., \& Leontiu, F. (2001). K Obosnovaniyu KlinikoPsikhologicheskogo Izucheniya Rasstrojstva Gendernoj Identichnosti [The basis for clinical-psychological study of gender identity disorder]. Voprosy Psyhologii, 6, 3-17. 
Sokolova, E.T., \& Nikolaeva, V.V. (1995). Osobennosti Lichnosti pri Pogranichnyh Rasstrojstvah Lichnosti i Somaticheskih Zabolevaniyah [Personality Traits in Borderline Personality Disorders and Somatic Illnesses]. Moscow: Argus.

Sokolova, E., \& Sotnikova, Yu. (2006a). Svyaz Psikhologicheskih Mehanizmov Zaschity s Affectivno-Kognitivnym Stilem Lichnosti [The Relationship between Psychological Defense Mechanisms and Affective-Cognitive Style of Personality]. Vestnik Moskovskogo Universiteta. Seriya 14: Psychologiya [Moscow University Bulletin. Series 14: Psychology], 2, 12-29.

Sokolova, E., \& Sotnikova, Yu. (2006b). Fenomen Suicyda: Kliniko-Psikhologicheskiy Rakurs [The Problem of Suicide: The Clinical Angle]. Voprosy Psikhologii, 2, 103-116.

Vygotsky, L. (1983). Istoriya Razvitiya Vyshih Psikhicheckih Funktsij [History of Development of Higher Psychological Processes]. In L. Vygotsky, Collected Works, vol. 3. Moscow: Pedagogika.

Watzlawick, P., Beavin, G., \& Jackson, D. (2000). Pragmatika chelovecheskih kommunikatsij [Pragmatics of Human Communication]. St.-Petersburg: Rech.

Winnicott, D. (2000). Ispolzovanie Objekta [The Use of an Object]. In A. Rossohin (Ed.), Antologiya Sovremennogo Psikhoanaliza [Anthology of Modern Psychoanalysis] (pp. 447-454). Moscow: Institut Psikhologii RAN.

Witkin, H. (1954). Personality through Perception. New York: Wiley Press.

Zeigarnik, B., Holmogorova, A., \& Mazur, E. (1989). Samoregulyaciya Povedeniya v Norme i Patologii [Self-Regulation of Behavior in Norm and Pathology]. Psikhologicheskij Zhurnal, 10(2), 122-132. 